\title{
BIOAKTIVITAS EKSTRAK METANOL DAUN PEGAGAN (Centella Asiatica L.) TERHADAP PERTUMBUHAN BAKTERI Mycobacterium Tuberculosis
}

\author{
Yusran, Asriani llyas, H. Asri saleh \\ Jurusan Kimia, Fakultas Sains dan Teknologi, UIN Alauddin Makassar \\ Email: iankizral@gmail.com
}

\begin{abstract}
Plants gotu kola (Centella Asiatica L .Urban) is a wild plant that efficacious as remedies traditional cure disease tuberculosis $(T B) . T B$ is disease contagious infection caused by bacteria mycobacterium tuberculosis.Research aims to understand the ability extract methanol leaves gotu kola red and leaves gotu kola green and determines the concentration optimal extract methanol leaves gotu kola red and leaves gotu kola green and to know the comparison between extract methanol leaves gotu kola red with an extract methanol leaves gotu kola green in inhibits the activity of mycobacterium tuberculosis. Extraction done with the methods maceration use methanol and continued with evaporation until obtained extract viscous .Testing antibacterial activity done in a microscopic observation drug susceptibility ( mods ) use plate petri dish 24 hole with the variation of concentration ie 20\%,40\%, 60\%, 80\% and $100 \%$.The results of testing show that extracts methanol leaves gotu kola red and leaves gotu kola green positive capable of inhibiting the growth of bacteria mycobacterium tuberculosis with inhibition optimal in concentration $80 \%$ and $100 \%$ characterized by the absence of growth bacteria colonies which are (-) or $0 \%$. Extract methanol leaves gotu kola green capable of inhibiting the growth of bacteria mycobacterium tuberculosis better than extract methanol leaves gotu kola red seen in concentration $40 \%$ and $60 \%$.
\end{abstract}

Keyword: plants gotu kola (Centella Asiatica L.Urban), mycobacterium tuberculosis, Microscopic Observation Drug Susceptibility (MODS).

\section{PENDAHULUAN}

Indonesia merupakan salah satu Negara yang memiliki keanekaragaman hayati di dunia. Wilayah hutan tropika Indonesia memiliki keanekaragaman hayati tertinggi ke-2 di dunia setelah Brazil. Sebanyak 40.000 jenis flora yang ada di dunia, terdapat 30.000 jenis dapat dijumpai di Indonesia dan 940 jenis diantaranya diketahui berkhasiat sebagai obat dan telah dipergunakan dalam pengobatan tradisional secara turun-temurun oleh berbagai etnis di Indonesia. Jumlah tumbuhan obat tersebut sekitar $90 \%$ dari jumlah tumbuhan obat yang terdapat dikawasan Asia (Maryati, 2010).

Allah swt. menurunkan air dari langit dan menumbuhkan berbagai macam tanaman semuanya mempunyai makna dan manfaat bagi kehidupan, salah satu contohnya yaitu sebagai obat. Penggunaan obat tradisional telah menarik perhatian dan kepopulerannya di masyarakat semakin meningkat. Salah satu penyebabnya adalah masyarakat telah menerima dan membuktikan manfaat dan kegunaan tumbuhan obat dalam pemeliharaan kesehatan. Salah satu 
tanaman yang berpotensi sebagai obat tradisional adalah pegagan (Centella asiatica (Linn) Urban) (Endamora, 2012).

Tanaman pegagan merupakan tanaman liar yang banyak tumbuh di berbagai tempat seperti di ladang, perkebunan maupun di pekarangan. Diberbagai Negara, pegagan sudah secara turun temurun digunakan sebagai obat tradisional untuk berbagai jenis penyakit. Di India dan di benua Afrika pegagan dipakai sebagai obat untuk mengobati berbagai penyakit, termasuk penyakit yang terkenal yang sangat sulit diobati.Sementara itu, di Prancis, pegagan sudah ditetapkan sebagai tanaman obat sejak tahun 1884.Daun pegagan juga ditetapkan sebagai obat dalam farmakope diberbagai Negara seperti Belanda, Meksiko, Spanyol, Venezuela dan India (Musyarofah, 2007).

Berbagai penelitian yang dilakukan oleh ahli farmakologi, ternyata pegagan memilki efek farmakologi yang sangat bermanfaat dalam menjaga kesehatan tubuh.Di samping itu, pegagan terbukti dapat mengobati berbagai macam penyakit dan salah satunya yaitu penyakit tuberkulosis.Pegagan mampu mengobati berbagai penyakit yang mematikan seperti kanker dan penyakit tuberkulosis, ini disebabkan karena pegagan mengandung golongan senyawa triterpen dimana senyawa ini merupakan metabolit sekunder yang memiliki potensi untuk menghambat bakteri patogen yang merupakan sumber penyebab penyakit tuberculosis (Winarto, 2013).

Tuberkulosis (TB) merupakan penyakit infeksi menular yang disebabkan oleh Mycobacterium tuberculosis.TB merupakan salah satu dari sekian banyak penyakit infeksi

menular yang masih tetap merupakan masalah besar bagi kesehatan masyarakat di dunia (Angraini, 2013). Survey World Health Organization (WHO) tahun 2006, menempatkan Indonesia sebagai penyumbang TB terbesar ketiga di dunia setelah India dan Cina (Mutia, 2012).

\section{Tujuan}

Tujuan yang dapat dicapai dari penelitian ini yaitu:

1. Untuk mengetahui kemampuan ekstrak metanol daun pegagan merah dan daun pegagan hijau dalam menghambat aktivitas bakteri Mycobacterium tuberculosis.

2. Untuk menentukan konsentrasi optimal ekstrak metanol daun pegagan merah dan daun pegagan hijau dalam menghambataktivitas bakteri Mycobacterium tuberculosis.

3. Untuk menentukan perbandingan antara ekstrak metanol daun pegagan merah dengan ekstrak metanol daun pegagan hijau dalam menghambat aktivitas bakteri Mycobacterium tuberculosis. 


\section{METODE PENELITIAN}

Alat

Alat-alat yang digunakan pada penelitian ini adalah gunting, kain blacu, toples kaca, blender, timbangan analitik, lemari asam, cawan penguap, pengaduk kaca, pipet mikro, gelas kimia $500 \mathrm{~mL}$, erlenmeyer $250 \mathrm{~mL}$, corong, tabung falkon, plat petri 24 hole, rak tabung, statif, klem, seperangkat alat destilasi, autoclave, inkubator, evaporator dan mikroskop fluorosense.

\section{Bahan}

Bahan yang digunakan adalah, aquades $\left(\mathrm{H}_{2} \mathrm{O}\right)$, aluminium foil, , daun pegagan merah (Centella asiatica L. Urban) dan daun pegagan hijau (Centella asiatica L. Urban), dimetil sulfoksida (DMSO), isolat bakteri mycobakterium tuberculosis, kertas timbangan, metanol $\left(\mathrm{CH}_{3} \mathrm{OH}\right)$ dan middlebrook $7 \mathrm{H} 9$.

\section{Prosedur Penelitian}

\section{Preparasi Sampel}

Mencuci sampel daun pegagan (Centella asiatica L. Urban) kemudian mengeringkan selama 2 minggu dengan cara diangin-anginkan. Memotong kecil-kecil sampel daun pegagan (Centella asiatica L. Urban) yang telah dikeringkan kemudian diblender (Mutia Devi Hidayati, 2012).

\section{Ekstraksi}

Menimbang sampel daun pegagan merah dan daun pegagan hijau sebanyak300 g. Memasukkan ke dalam wadah maserasi (toples).Menambahkan pelarut metanol.Merendam sampel daun pegagan kering selama 1 x 24 jam sebanyak 3 kali.Menyaring sampel daun pegagan menggunakan kain blacu kemudian mengambil ekstrak sampel.Memasukkan filtrat dalam labu evaporator kemudian mengevaporasi sampai diperoleh ekstrak kental. (Ahyar Ahmad, 2014 dan Bambang Sudewo, 2012).

\section{Uji Bioaktivitas Antibakteri}

Pengujian aktivitas antibakteri dilakukan menggunakan metode Microscopic Observation Drug Susceptibility (MODS) mengunakan plat petri 24 hole. Pertama membuat kontrol (-) dengan memipet $100 \mu \mathrm{L}$ DMSO ke dalam 3 hole pada plat petri. Memipet masing-masing 100 $\mu \mathrm{L}$ antibakteri $20 \%, 40 \%, 60 \%, 80 \%$ dan $100 \%$ ke dalam 3 hole pada plat petri. Membuat kontrol obat dengan memipet $100 \mu \mathrm{L}$ rifampisin ke dalam 3 hole pada plat petri. Kemudian memipet $900 \mu \mathrm{L}$ isolat bakteri mycobacterium tuberculosis ke dalam kontrol (-), kontrol obat 
dan antibakteri. Menghomogenkan dengan menggoyang-goyangkan plat petri. Membuat kontrol (+) dengan memipet $1000 \mu \mathrm{L}$ ke dalam 3 hole pada plat petri. Diinkubasi pada suhu $37^{\circ} \mathrm{C}$ selama 2 minggu (Anita, 2014).

\section{HASIL DAN PEMBAHASAN}

Tabel 1. Hasil Uji Bioaktivitas Antibakteri Ekstrak Metanol Daun Pegagan Merah terhadap Mycobacterium Tuberculosis

\begin{tabular}{ccc}
\hline \multirow{2}{*}{$\begin{array}{c}\text { Konsentrasi } \\
\%(\mathbf{b} / \mathbf{v})\end{array}$} & \multicolumn{2}{c}{ Pertumbuhan Bakteri } \\
\cline { 2 - 3 } 20 & Minggu pertama & Minggu kedua \\
40 & ++ & +++ \\
60 & + & + \\
80 & + & + \\
100 & - & - \\
$\mathrm{K}(-)$ & - & - \\
$\mathrm{K}(+)$ & ++ & +++ \\
$\mathrm{K} \mathrm{O}$ & ++ & +++ \\
\hline
\end{tabular}

Keterangan:

K (-) : Kontrol (-) yaitu DMSO + isolat bakteri

$\mathrm{K}(+)$ : Kontrol (+) yaitu isolat bakteri

K O : Kontrol obat rifampisin yaitu rifampisin + isolat bakteri

- $\quad$ : Tidak terjadi pertumbuhan bakteri(0\%)

$+\quad$ : Terjadi pertumbuhan bakteri sedikit $( \pm 25 \%)$

$++\quad$ : Terjadi pertumbuhan bakteri sedang $( \pm 65 \%)$

$+++\quad$ : Terjadi pertumbuhan bakteri banyak $( \pm 95 \%)$ 
Tabel 2. Hasil Uji Bioaktivitas Antibakteri Ekstrak Metanol Daun Pegagan Hijau terhadap Mycobacterium Tuberculosis

\begin{tabular}{ccc} 
Konsentrasi & \multicolumn{2}{c}{ Pertumbuhan Bakteri } \\
\cline { 2 - 3 }$\%(\mathbf{b} / \mathbf{v})$ & Minggu pertama & Minggu kedua \\
\hline 20 & ++ & +++ \\
40 & + & + \\
60 & + & + \\
80 & - & - \\
100 & - & - \\
$\mathrm{K}(-)$ & ++ & +++ \\
$\mathrm{K}(+)$ & ++ & +++ \\
$\mathrm{K} O$ & ++ & +++ \\
\hline
\end{tabular}

Keterangan:

K (-) : Kontrol (-) yaitu DMSO + isolat bakteri

$\mathrm{K}(+)$ : Kontrol (+) yaitu isolat bakteri

K O : Kontrol obat rifampisin yaitu rifampisin + isolat bakteri

- $\quad$ : Tidak terjadi pertumbuhan bakteri(0\%)

$+\quad$ : Terjadi pertumbuhan bakteri sedikit $( \pm 25 \%)$

$+\quad$ : Terjadi pertumbuhan bakteri sedang $( \pm 65 \%)$

$+++\quad$ : Terjadi pertumbuhan bakteri banyak $( \pm 95 \%)$

Berdasarkan hasil penelitian yang ditunjukkan pada tabel 1 dan tabel 2 maka dapat diketahui bahwa daun pegagan merah dan daun pegagan hijau mampu mengambat pertumbuhan bakteri mycobacterium tuberculosis. Bioaktivitas antibakteri daun pegagan merah diperlihatkan pada table1 yaitu pada konsentrasi $20 \%$ pada minggu pertama menunjukkan adanya pertumbuhan bakteri dengan jumlah koloni bakteri yaitu $\pm 65 \%$ dan pada minggu kedua pertumbuhan bakteri meningkat dengan jumlah koloni yaitu $\pm 95 \%$.Pada konsentrasi $40 \%$ pada minggu pertama menunjukkan adanya pertumbuhan bakteri dengan jumlah koloni bakteri yaitu $\pm 25 \%$ dan pada minggu kedua pertumbuhan bakteri tetap dengan jumlah koloni yaitu $\pm 25 \%$. Pada konsentrasi $60 \%$ pada minggu pertama menunjukkan adanya pertumbuhan bakteri dengan jumlah koloni bakteri yaitu $\pm 25 \%$ dan pada minggu kedua pertumbuhan bakteri tetap dengan jumlah koloni yaitu $\pm 25 \%$. Pada konsentrasi $80 \%$ dan $100 \%$ pada minggu pertama dan minggu kedua menunjukkan tidak adanyatanda-tanda pertumbuhan koloni bakteri yang ditandai dengan jumlah koloni $0 \%$.

Pada kontrol (+) dan kontrol (-) pada minggu pertama menunjukkan adanya pertumbuhan bakteri dengan jumlah koloni yaitu $\pm 65 \%$ dan pada minggu kedua pertumbuhan bakteri miningkat yaitu $\pm 95 \%$. Pada kontrol obat rifampisin pada minggu pertama menunjukkan adanya 
pertumbuhan bakteri dengan jumlah koloni yaitu $\pm 25 \%$ dan pada minggu kedua pertumbuhan bakteri miningkat yaitu $\pm 95 \%$. Berdasarkan hasil pengamatan pada tabel 1 menunjukkan bahwa semakin tinggi konsentrasi ekstrak metanol daun pegagan merah maka semakin berkurang jumlah koloni bakteri mycobacterium tuberculosis. Hal ini terjadi karena semakin tinggi konsentrasi ekstrak metanol daun pegagan merah maka semakin banyak pula senyawa golongan triterpenoid yang terkandung dalam ekstrak sehingga mampu menghambat pertumbuhan bakteri mycobacterium tuberculosis.Berdasarkan hasil tersebut maka dapat dikatakan bahwa daun pegagan merah mampu mengambat pertumbuhan bakteri mycobacterium tuberculosis.

Bioaktivitas antibakteri daun pegagan hijau diperlihatkan pada tabel 2 yaitu pada konsentrasi $20 \%$ pada minggu pertama menunjukkan adanya pertumbuhan bakteri dengan jumlah koloni bakteri yaitu $\pm 65 \%$ dan pada minggu kedua pertumbuhan bakteri meningkat dengan jumlah koloni yaitu $\pm 95 \%$.Pada konsentrasi $40 \%$ pada minggu pertama menunjukkan adanya pertumbuhan bakteri dengan jumlah koloni bakteri yaitu $\pm 25 \%$ dan pada minggu kedua pertumbuhan bakteri tetap dengan jumlah koloni yaitu $\pm 25 \%$. Pada konsentrasi $60 \%$ pada minggu pertama menunjukkan adanya pertumbuhan bakteri dengan jumlah koloni bakteri yaitu $\pm 25 \%$ dan pada minggu kedua pertumbuhan bakteri tetap dengan jumlah koloni yaitu $\pm 25 \%$. Pada konsentrasi $80 \%$ dan $100 \%$ pada minggu pertama dan minggu kedua menunjukkan tidak adanyatanda-tanda pertumbuhan koloni bakteri yang ditandai dengan jumlah koloni $0 \%$.

Pada kontrol (+), kontrol (-) dan kontrol obat rifampisin pada minggu pertama menunjukkan adanya pertumbuhan bakteri dengan jumlah koloni yaitu $\pm 65 \%$ dan pada minggu kedua pertumbuhan bakteri miningkat yaitu $\pm 95 \%$. Berdasarkan hasil pengamatan pada tabel 2 menunjukkan bahwa semakin tinggi konsentrasi ekstrak metanol daun pegagan merah maka semakin berkurang jumlah koloni bakteri mycobacterium tuberculosis. Hal ini terjadi karena semakin tinggi konsentrasi ekstrak metanol daun pegagan hijau maka semakin banyak pula senyawa golongan triterpenoid yang terkandung dalam ekstrak sehingga mampu menghambat pertumbuhan bakteri mycobacterium tuberculosis.

Proses mekanisme penghambatan ekstrak metanol daun pegagan terhadap bakteri mycobacterium tuberculosissama dengan kinerja obat rifampisin yaitu menghambat pada saat proses sintesis protein. Proses sintesis protein pada bakteri terdiri dari 2 tahap yaitu tahap transkripsi dan tahap translasi. Tahap transkripsi adalah tahap penguraian molekul DNA ke bentuk RNA dengan bantuan enzim RNA polimerase yang melekat pada ujung terminalnya. Proses penghambatan bakteri terjadi pada tahap ini, dimana enzim RNA polimerase lebih cenderung melekat pada senyawa asam asiatikosida sehingga kehilangan fungsinya terhadap pembentukan RNA dan proses sisntesis protein terhambat sehingga pertumbuhan bakteri tidak bertambah atau bahkan berkurang.

Berdasarkan hasil tersebut maka dapat dikatakan bahwa daun pegagan mampu mengambat pertumbuhan bakteri mycobacterium tuberculosis dan penghambatan optimum ekstrak metanol daun pegagan terjadi pada konsentrasi $80 \%$ dan 100\%.Berdasarkan hasil pengamatan secara visual dengan mikroskop fluoresensemaka dapat diketahui bahwa ekstrak 
metanol daun pegagan hijau mampu mengambat pertumbuhan bakteri mycobacterium tuberculosis lebih baik dari pada ekstrak metanol daun pegagan merahyang terlihat pada konsentrasi $40 \%$ dan $60 \%$.

Hal ini diperkuat dengan penelitian sebelumnya (Vinay Kumar dkk, 2014)bahwa daun pegagan mengandung senyawa bioaktif golongan triterpen yaitu asam asiatikosida, asam madekasat dan asam madekasosida yang mana senyawa ini efektif dalam menghambat pertumbuhan bakteri mycobacterium tuberculosis serta dijelaskan dalam buku tentang pengobatan herbal (Winarto, 2009)bahwa daun pegagan mampu mengobati penyakit tuberkulosis dengan mengkonsumsi secara langsung.

\section{PENUTUP}

\section{Kesimpulan}

Berdasarkan hasil penelitian yang telah dilakukan, maka dapat disimpulkan bahwa:

1. Ekstrak metanol daun pegagan merah (centella asiatica L. Urban) dan daun pegagan hijau (centella asiatica L. Urban) positif mampu mengambat pertumbuhan bakteri mycobacterium tuberculosis.

2. Ekstrak metanol daun pegagan merah dan daun pegagan hijau mampu mengambat pertumbuhan bakteri mycobacterium tuberculosis secara optimal pada konsentrasi $80 \%$ dan $100 \%$ yang ditandai dengan tidak adanya pertumbuhan jumlah koloni bakteri (-) atau $0 \%$.

3. Ekstrak metanol daun pegagan hijau mampu mengambat pertumbuhan bakteri mycobacterium tuberculosis lebih baik dari pada ekstrak metanol daun pegagan merah yang terlihat pada lampiran gambar hasil pengamatan yaitu pada konsentrasi $40 \%$ dan $60 \%$.

\section{DAFTAR PUSTAKA}

Abd Gafur, Maryati.“Isolasi Dan Identifikasi Senyawa Flavonoid dari Daun Jamblang (Syzygium Cumini)".vol. 1, no. 1 (2010), h. 1.

Ahmad, Ahyar dan Muh. Nasrum Massi.The Antituberculosis Drug Rifampicin is Activated By 2', 5'-Dimethyl Benzopelargonolactone from The Leaf of Coleus Atropurpureus L. Benth. International Journal of Pharma and Bio Sciences. Vol. 5, no. 1 (2014), h. 4.

Angria, Milsa."Pembuatan Minuman Instan Pegagan (Centella Asiatica) dengan Citarasa Cassia Vera". Skripsi. Padang: Fakultas Teknologi Pertanian Universitas Andalas, 2011.

Anita, at.al. "Evaluation of the Microscopic-Observation Drug-Susceptibility Assay Drugs Concentration for Detection of Multidrug-Resistant Tuberculosis". vol. 08, no. 05 (2014): h. 257. 
B, Devi Hidayati, Mutia dan Taslim Ersan."Kajian Antituberkulosis pada Ekstrak N-heksan Mundu Alas (Mammea Odorata Raf)". (2012): h. 1.

Girsang, Merryani.“Mycobacterium Penyebab Penyakit Tuberculosis Serta Mengenal Sifat-sifat Pertumbuhannya di Laboratorium". Pusat Biomedis dan Teknologi Dasar Kesehatan Badan Litbang Kesehatan Jakarta (2013): h. 1.

Kumar, Vinay, dkk, "Effect of Centella asiatica against anti tuberculosis drugs-induced hepatotoxicity: Involvement of mitochondria and oxidative stress", vol. 3, no. 5 (2014), h. 310-311.

Mora, Enda dan Armon Fernando."Optimasi Ekstraksi Triterpenoid Total Pegagan (Centella asiatica (Linn.) Urban) yang Tumbuh di Riau". vol. 1, no. 1 (2012): h.1.

Musyarofah, Neni, dkk."Respon Tanaman Pegagan (Centella asiatica L.Urban) Terhadap Pemberian Pupuk Alami di Bawah Naungan”. vol. 35, no. 3 (2007): h. 1. 